\title{
Assault on the Women in Margaret Atwood`'S Bodily Harm: an Analysis
}

\author{
Dr. K. Srinivasan
}

\begin{abstract}
Among the Canadian Women novelists who pionner the causes of women, Margaret Atwood plays a major role. She is the most opted writer is the midst of literary critics. Through her works, she fights for the rights of women. She tries to define her feminism as human equality and freedom of choice. She attacks the narrow and dominant social construction of identity and gender. There is a sort of pleading for healthy relationships between man and women. This Paper studies and explores the feminist perspective both us concept and reality in the novel Bodily Harm. The novel is a post-feminist text which brings out the legal, economic, social and political conditions of women that are still bleak. The novel is a kind of thearpy to gender victimization and presents the abuse, torture, mutilation and destruction of female body in hospitals and prisons for the purpose of male domination.
\end{abstract}

Key Words: Bleak, Domination, Identity, Post-feminism, Victimization

\section{Introduction}

Margret Atwood a prolific writer, versatile social critic, a keen and perceptive observer to life has produced novels, books of poetry, short story collections, literary criticism to her credit. She writes from her sense of the enormous complexity, not only of the relationship between man and woman, but also those abstract ideas such as Art and life, Form and Content, Writer and Critic. Her writings are involved with human rights of women. Thus, her feminist ideology is larger and non- exclusive picture as provided in her novels in general. Her fiction is her reflection of the violation of women rights.

\section{Feminist Ideology}

Atwood's feminist ideology has been powerfully expressed through her fiction. It is explicitly stated as her effort to define her feminism as human equality and freedom of choice. Her fiction provides a comprehensive review of the problems that women confront in attaining full recognition and enjoyment of all human rights and fundamental freedom. In short, it can be stated that her novels faithfully reflect the dictum that human rights are women's rights and women's rights are human rights.

Atwood attacks the narrow and dominant social constructions of identity and gender. Her novels expose the silent and hidden operation of gender. They transcend gender and plead for healthy human relations between man and woman. Through her novels, she not only demands demolition of the gender system, namely the real source of women's oppression, but also envisions a new world in which men and women are equals at every level of existence. In that world, all women enjoy human rights and lead a stable, peaceful and healthy life. In that away, she recommends an alternative picture of reality. In Bodily Harm, she explores feminist perspective both as concept and a reality.

\section{Bodily Harm}

Atwood's best known post-feminist text Bodily Harm (1981) demonstrates that the legal, economic and social, and political conditions of women are still bleak. It addresses itself to the "violation of human rights". Though women have become conscious of their- rights, they are exploited and suppressed. They are deprived of their basic human rights like all the weak and powerless in the world. It would be a mistake to assume that everything has changed. The goal of the feminist movement has not been achieved.

This novel draws attention to the horrifying status of women in the Post feminist era. The novel is a different kind of therapy to gender Victimization. Howells in his Margaret Atwood says “... In Bodily Harm the female bodies are all passive distorted, dismembered or coerced. Whiteness to the sexual power politics of the Berger epigraph" (120)

The novel presents poignantly the abuse, torture, mutilation and finally the destruction of female body in hospital beds and prison cells for purposes of male domination -sexually. Ironically, it is an inscription of the female body and by connecting hospital room and jail and cell dramatically she presents the injury to the female body that result from its confinement.

Renate Welford is the child of an irresponsible man who has abandoned 
his family for a mistress in Toronto. In an unhealthy and joyless environment, she is brought by her grandparent in Griswold. By her grandmother's traditional approach, her child hood is suppressed and spoiled. So she detests her servile existence. To lead a life of freedom, she leaves the place. She begins her adult life as a versatile writer in Toronto. She gets commissioned to write articles for Visor, male- oriented journal and Pandora, a female oriented journal. So it offers her enough scope to write about both men and women.

While writing a piece called The Young and Salver for Visor, she comes in contact with Jake who works as a designer for a packaging company. In spite of her intelligence she allows herself to be trapped in the evil designs of Jake. As he does things, he tricks to use pack her. She realizes that his interest in her is limited to the gratification of his carnal desires. Jake disguises sexual desire as "love" and wield love as a weapon rather than as a gift. For him, love is a crude game intended to hurt women as such as he could. In one such encounter, she feels that Jake is out to strangle her:

Jake liked to pin her hands down, he liked to her so she couldn't move. He liked that, he like thinking, of sex as something he could with at. Sometimes he really hurt her, once he put his arm across her throat and she really did stop breathing.(p.207)Emma Parker has made an important observation on this scene of strangulation, Strangulation is a method of mare domination, since by stopping the life -giving flow between brain and body it physically enforces the ideological dichotomy between mind and body which forms the basis of the hierarchical system of gender polarity, which informs the whole of Western Metaphysics and culture. (p.363).

There is a streak of sadism in Jake's love. He imagines love with Rennie as apretended rape. He enjoys overpowering her sexuality. He accuses women of having the voracious female animalistic desire. He remarks that women should be locked in cages. He has an exploitative and debased view of the female sex. He considers her only an object of sex. She feels highly humiliated, when she brought a new lady into her home. He furbishes her apartment with naked pictures. Though she understands that he would pack her up, she wants to live with him.

Rennie gets trapped when she is diagnosed of breast cancer by Dr. Daniel Luoma, a male gynecologist. He is another male - brutality that she had to encounter with. As the doctor develops a passion for her, she has to choose between "sexual mutilation by the surgeon or death by cancer" in the hospital bed. To save her life, she engages in an affair with him who violates the professional ethics. She is emotionally disturbed by the mark of scar on her body. He feels ill-at-ease in the company of him following her mastectomy. He imagines the scar on her breast as a kiss of death or her. He abandons her feeling that tire is not enjoyable with diseased woman.

Rennie is now aware that she has been the raw-material, violated and doctored by Daniel. She discovers that Dr. Daniel is a victimizer who directs technological assault on women in the guise of medicine and surgery. Thus Daniel embodies the paradoxes of patriarchy. By creating the writer as both woman and a patient in Bodily Harm, Atwood confronts and demystifies masculine authority in the figure of the doctor who hears and destroys.

Rennie regrets that she has Atwood herself to be used, manipulated and abused by Jake and Daniel as a kind of "raw material" according to their own impoverished values. Her maiden love leaves her shattered physically and emotionally. A man leaves a coir of rope on her bed in Toronto, on the following day of Jake's departure and the dead - end relationship with Daniel. The coiled rope is a sign that she has been confined and fettered by her situation as a woman. It gives her some kind of new awareness.

In the Book Waiting for the Rescue, Rennie boys have been maimed, dismembered, altered and fragmented. It symbolizes the crippled human beings ail over the world. She realizes that human malice is as dangerous as cancer. As Dorothy Jones says, Fear of death by a disease like cancer is weighted against those threats to life which result from human malice - poverty, malnutrition and political violence. (p.86-87) The bodily harm done to her makes her realize what harm she has done to her otherwise. Her mental anguish clears the fog in her mind and attitude. The vicious force inside her body is the symbolic representation of the vicious forces in the outside world. Rennie gets involved in love with Paul, a tourist guide in the Caribbean island. She feels to strike a meaningful relationship with him as he does not abandon her on the grounds of scar. She realizes that is an immature person interested in sporting and wielding a gun needlessly. She beings to detest him as she is very much afraid of the very sight of gun. He is not ready to give himself up in love totally. She is very much stunned by his dry attitudes. To him, she is a soft of "house guest". She is gradually disillusioned with him. This marks another meaningless relationship with man. Rennie feels that involvement in love affairs is like running bare-foot along a street covered with broken bottles. She realizes her female passivity and her ability to establish a meaningful relationship with any one of her male associates. She cries then "I should take my body and run. I do not need another man. I'm not Supposed to expect anything from .....”(p,22)

The Jake -Daniel -Paul trinity symbolizes her animus projections. They help her realize the inner voice of her serf, she is compelled to peep inside and listen to what her inner voice says. They invite her to act and react instead of remaining a dispassionate observer of happenings.

Rennie's association with Jocasta, a feminist activist, raises her consciousness and helps her understand better the villainous attitude and victimizing nature of the males. She is convinced that women's liberation 
continues to be a distant dream. A lot has to be done to realize the desired goals. Jocasta wishes to reverse the whole of men and women.

A long time ago, a year ago Jocasta said, I think it would be a great if all the men were turned into women and all the women were turned into men, ever just for a day. They they'd all they got changed Back, I mean. (p.156) Jocasta's assessment of man -woman relationship illuminates her. It also serves as a "feminist therapy". She assesses her love relationships from a fresh perspective. She represents a complete and complex socio- gender system. Under her influence, she publishes her article "Burned out" on the alleged death of the women's movement. In this article, she writes why women are degraded to take vocations like "bitching" and "trashing". Other women were just so difficult to work with, you never knew where you stood with them. And it all went on behind your back at least with men it was out on the table, they said and Rennie busily wrote it all down (p,63) When Rennie writes about pornography as an art form from the "women's angle" for Visor, her research leads her to the studio of a male porn artist called Frank. While interviewing him, she sees there life sized tables and chairs featuring women muzzled and locked in odd positions. She realizes how art is used to depict women as ugly creatures meant for violence. From his remarks, she understands about the social and moral functions of writing.

Along with Jocasta, she visits Toronto policemen's pornography museum. She witnesses a lot of visual evidence of male sadistic fantasies of power and violence against women. She is basically a committed moral women. She gets drifted away in her so called search for love and affection.

Rennie gets horrified by the sight of the film clips of nude women indifferent postures of brutality displayed at the museum. Some of the films project women copulating with animals leading to the mutilation of their bodies. The purpose of all ugly and horrible films seems to exhibit bodies of women as maps of violence. It also indicates file marker's utter depth of human depravity, cruelty and violation of human rights. It points out the abuse of women in the so-called civilized countries which are primitive as for as brutalizing of a woman's body is concerned.

Rennie realizes that women are stripped off their identity. They are reduced to raw- materials. She also feels that men destroy women's individuality in a subtle and invisible manner with a help of cultural codes. She realizes that she too is a part of the "raw material" in the words of Howells,

Bodily Harm is another version of writing the female body... from the point of view of women whose own body is already damaged by cancer and mastectomy. From this 'post operative' angle she scrutinizes social myths of femininity, medical discourse on breast cancer and the rhetoric of pornography; this novel is emphatically not about bodily pleasures but about bodily harm. (p.106)

Rennie is commissioned to do a travel piece for Visor. It takes her to the Caribbean island. She finds her tragedy reflected in the tragedy of mute and innocent masses all over the world. The political scene in Caribbean island has no place for love, decency and humanity. The voters list on the island contains names of the dead people while the names of the many living are excluded from it. Floods are like a boon to the rulers because they fetch charity and aid which are used for purchasing votes.

Women are treated as non-entities. They are tortured and ever sliced off into pieces. Rennie discovers different victims in the Caribbean island. So she feels shattered. She soon learns that women are not very different from common people. Women are powerless and hence abused, Thus her travel piece expands and extends the implication of the term "woman", to cover all the victimized and oppressed people in the world. Jaidev's observation finds suitable place here, "Woman becomes a metaphor for all those who are damaged and abused only because they are powerless...." (p.25)

The freedom and identity of women are only delusions. She realizes that people enjoy torturing women. Marsdon, the campaign manager of elections for prince of peace in the Caribbean island beats and tortures a woman by making her naked and covering her with cow-itch. Then he tied her to a tree near an ant hill, the stinging kind. Listening to her scream, he drank rum and left her there for five hours, till she was swollen up like a balloon. The islanders look at this cruelty on woman as mere silent spectators because he had a mean reputation and also it was a man-woman thing. She recognizes that the Caribbean is as bad as Canada, the representative of the civilized world.

Rennie visits women prisoners in the Caribbean prison along with Dr.Minnow who is known for his rebellion against the tyranny of the government. Soon she is accused of massive involvement in the island's current revolution and in the political affairs. She is accused of being an outraged tourist and so she is arrested. She comes in contact with her fellow prisoner, Lora Lucas.

Lora's tales of pain and brutality completely shattered Rennie's s over- confidence in women's liberation. Her own vicious stepfather lives with her in the cellar. She leads a life terror under the gross exploitation of her stepfather. She narrates her father's inhuman attitude.

If he hit me it was like the weather, sometimes it rains, sometimes it doesn't. He didn't hit me because I was bad, like I used to think. He hit me because he could get away with it and nobody could stop him. That's mostly why people do stuff like that because they can get away with it. (p.113). 
Lora's mother is helplessly dependent on her husband and so she go to the rescue of Lora ever when her husband used to threaten his step - daughter with sexual assault. Ultimately, she stabs him as he tries to rape her and leaves the place. Her account of her childhood brings home to Rennie the vulnerability of the female.

Lora's experience in working on a boat turns out to be worse still. She is shocked to know that all the mean around expected her to sleep with them. She has to either comply with them or lose the job. She mourns referring to the worker's attitude towards women: “... Funny you look pretty cheap to me, he said. I may be pretty but I'm not cheap, I said I'. Like a lawyer, what you.re paying for is The experience ...” $(p, 214)$

Lora's pathetic experience in Canada and in the Caribbean shock Rennie feminist sensibility. She witnesses low Lora reluctantly obliges the prison guards for sex in return for news about prince of peace, her lover. Lora is sexually assaulted, beaten, mutilated and killed by the policemen.

Rennie is moved by the sight of the dead body of Lora. She feels a sense of empathy with her. She feels touches and finally licks the dead face of Lora as the animals do their newly born offspring. This is how she identifies herself with Lora's tragedy. She rejects her submissive rote as a woman. She is prepared to speak about the disturbing thought both about all the exploited people and women in particular. She exposes it visible through her writing and makes her immortalize in the form of the book. She imagines a future which will be different from the present.

Rennie asserts that "bodily harm" is everywhere both inside and outside of

the prison, both in civilized and uncivilized countries and both in political field and the prison, both in civilized and uncivilized countries, and both in political filed and personal life. There are no fixed hard boundaries to "bodily harm". So she uses her pen as a "weapon" to depict her experiences' she takes pledge to devote her life in the service of the weak and women. So she narrates and publishes her experiences in the form of a travelogue called Bodily Harm. Helene Cixoux has made a commendable observation in this regard, "...Ronnie puts women into the text-has into world and into History-by her own movement of travelogue..." (The Laugh of the Medusa, trans, Keith Cohen \& Paula Cohen, Signs 1.4, Summer, L976, P.875)

\section{Conclusion}

Margaret Atwood envisions an organized society where human beings are united and organize for a common cause. As her name "Renate wellford" implies "born again". She has to born anew and lives in the present with a meaningful message for the future. She tries to create a female space, female society, female religion as an antidote to male domination.

[1]. Atwood, Margaret. Bodily Harm, London: Vintage, 1996

[2]. Howells, coral Ann. Margaret Atwood: Macmillan Modern Novelists Series.

[3]. Cixous, Helene. The Laugh of the Medusa. Trans. Keith Choen and Paula Cohen. Signs 1.4 (Summer 1976): 875 - 93.

[4]. Jaidev. "Women as Metaphor: Note on Atwood's Feminism". The Indian Journal of English Studies 25 (1985): 111-117.

[5]. Parker, Emma. "You are what you Eat: The Politics of Eating in the Novels of Margaret Atwood". Twentieth century Literature. 41.3 (Fall 1995): $349-68$.

[6]. Waiting for the Rescue: A Discussion of Margaret Atwood's Bodily Harm.Kunapipi vi.3 (1984). 